\title{
Egy mai háromosztatú alföldi lakóház anyagi kultúrája
}

\author{
RÁCZ MIKLÓS \\ Magyar Nemzeti Múzeum - Nemzeti Örökségvédelmi Központ, Műemléki Kutatási Osztály \\ H-1113 Budapest, Daróci út 3., miklos.racz@mnm-nok.gov.hu
}

Rácz, M.: Material culture of a contemporary vernacular house in the Great Hungarian Plain

Abstract: An archaeological study of an abanadoned vernacular house in central Hungary focusing on material culture as well as the building archaeology of the traditional structures. With 20 figures.

Keywords: contemporary archaeology, building archaeology, vernacular architecture

Egy alföldi településen 2000 táján elhagyottá vált, és pusztulásnak indult egy hagyományos lakóház. Az épület és a telek megfigyelésével és dokumentálásával - elsősorban műemlékvédelmi indíttatással - ekkor kezdtem el foglalkozni. A megfigyelések általam kiemelt régészeti és építéstörténeti tanulságait és eredményeit az alábbiakban szeretném összegezni.

\section{A vizsgált épület: a lelőhelyképződés kezdetének dokumentálása, mint kísérleti régészeti eszköz}

A Tiszaföldvár északnyugati szélén, egy két szintre tagolódó telek felső részét elfoglaló gazdasági udvaron álló lakóház, istálló, ól és árnyékszék épületegyüttese az 1990-es évek végén vált lakatlanná (1-10. képek). A lakóhely elhagyásához vélhetőleg a lakóház nádfedésében keletkezett károk vezettek, melyek kijavítását az idős lakó már nem vállalta, és bizonytalanná vált otthona helyett a szociális ellátást választotta.

Az északnyugati szélnek kitett tető tovább pusztult, a beázások miatt elsősorban az eresztájon megindult a szarufák korhadása, a külső falak mentén koncentrálódó beázások helyén az átázott padlássaralás alatt a födém nádborítása egyre nagyobb felületeken elkorhadt és beszakadt, s a födémgerendák korhadása is megkezdődött. A beázás miatt beomlott a konyha vályogból és téglából boltozott szabadkéménye, ezzel a konyha területén közel 1 méter vastag omladékréteg keletkezett, mely beborította az épített tüzelőpadkát és tǔzhelyet. A nagyobb beázások helyén a faltetők anyaga lemosódott és erodálódott, a falkoronákon és a falak tövében gyomnövények és gyorsan növő fák eresztettek gyökeret (9. kép). A beázások nyomán egy - feltehetőleg korábbi, rosszul tömörített gödörbetöltésre alapozott - osztófal megsüllyedt. A padlást a tetőfedés nádtörmeléke borította be.

Az ingatlant az elhunyt lakó örökösei nem tudták, és nem is kívánták fenntartani. A népi építészeti jelentősége miatt korábban helyi rendelettel védett épületet az önkormányzat menthetetlennek ítélte, és védettségét visszavonták.

A következő években előreláthatólag befejeződött volna az épület természetes úton való pusztulása: a pusztulás kezdetének dokumentálása révén egy valós lelőhelyképződés körülményeit dokumentálhatjuk. ${ }^{1}$

\section{Környezet és településtörténet}

Tiszaföldvár egy dél felé háromszög alakban szélesedő kiemelkedésen települt (1-2 kép). ${ }^{2}$ A településről viszonylag késői és kevés középkori forrás ismert³, 1467-ben a földvári (Dunaföldvár) apátság birtoka volt. Az egykori belterületet a kiemelkedés északi csúcsától mintegy 750 méterre egy közelebbről nem datált, mára betöltött árok, vélhetőleg egykori védmű, a Sánc határolta (2. kép). A belterületet a többi oldalról az ártér övezte, amelyben korábbi Tisza-holtágak medrei húzódnak.

1 A klasszikusan néprajzi vonatkozású emléket tanulmányomban a néprajzi szempontok elsőbbsége helyett régészeti szempontokra: az időbeli átalakulások anyagi nyomaira koncentrálva, és az elhagyott ház tárgyegyüttesét leletanyagként értelmezve vizsgálom. A kortárs régészet vonatkozásában inspirációként szolgáltak többek között Rachael Kiddey-nek és John Schofieldnek a British Archaeology folyóiratban megjelent cikkei így pl. Kiddey - Schofield 2010. (http://www.archaeologyuk.org/ba/). A kortárs falusi lakóépületek történetének anyagi nyomaira irányuló kutatások a néprajzkutatók tevékenységéhez kötődnek, elsősorban a házbontások, de a helyszíni felmérések kapcsán is, és e területnek ma már jelentős szakirodalma van. Ezek a kutatások - különösen a házbontások esetén - több esetben a komplexitás és a teljesség igényével vizsgálják és dolgozzák fel egy-egy épület változásait. Itt csak a közelmúlt jelentősebb példáira utalva: Sabján 1998., Berényi - Buzás 2002., Tóth 2005., Holcsek - Balázsik 2009., Bálint 2010., Buzás - Vass 2011. A lakóházakra és lakáskultúrára általában: Balassa 1997.

2 A településröl összefoglalóan: Kelemen - Pató - Szlankó 2002.

3 Bagi 2002. 53. 
A szélső lakóházak a dombhát meredeken kiemelkedő szélén, ennek vonalára és a vele párhuzamosan futó utcára merőlegesen állnak. A település két partél menti utcája között sűrű, zugos településszerkezet alakult ki.

A szélső házsorok esetében - így a tárgyalt telek esetében is - a telek felső része gazdasági udvar, míg az alsó rész, mely az egykori ártér része, háztáji kert.

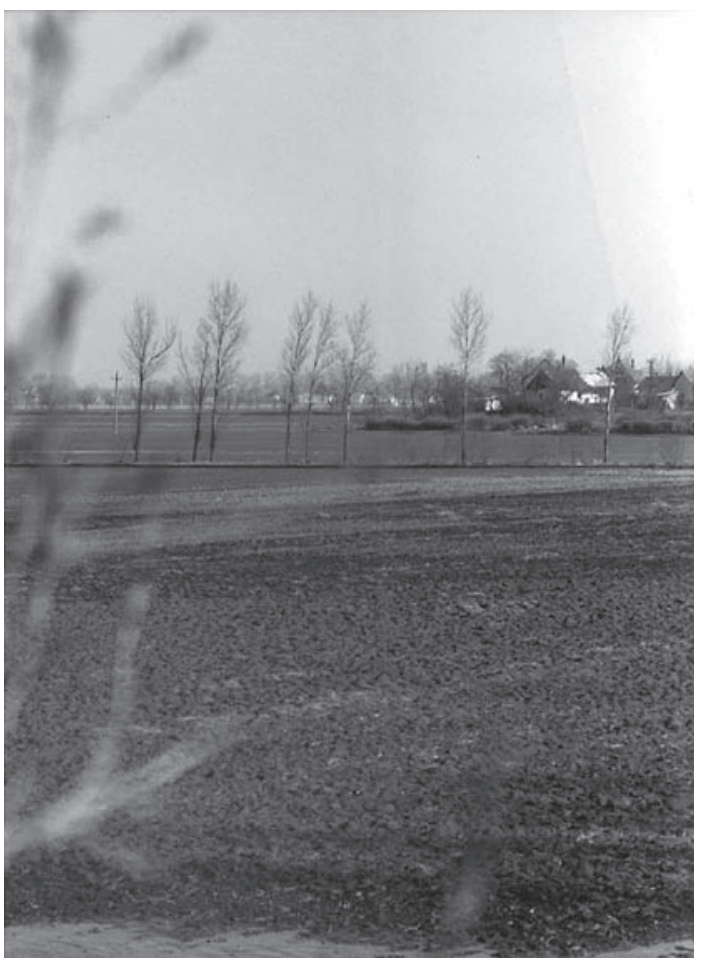

1. kép: Tiszaföldvár északi része nyugat felöl nézve, hátul a tárgyalt lakóház, 2000.

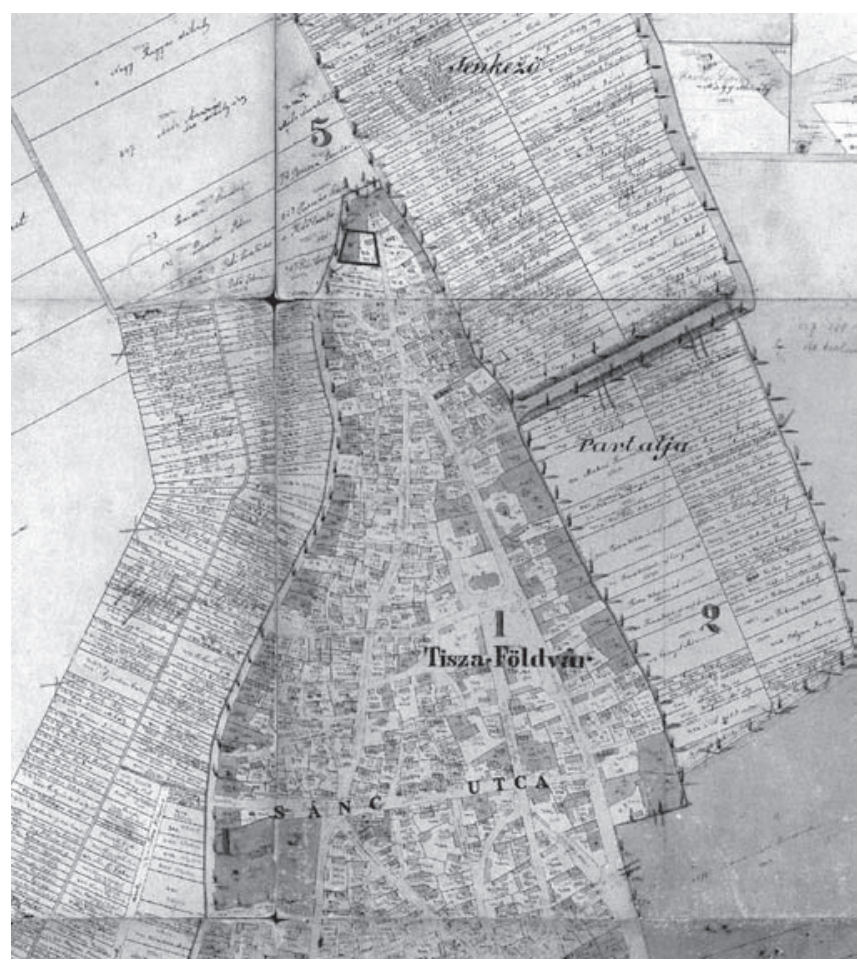

2. kép: Tiszaföldvár kataszteri térképe, 1870-1890 körül, a telek keretezéssel jelölve

\section{A háromosztatú, szabadkéményes háztípus eredete, előzményei}

A többosztatú, kívülről fütött szobával rendelkező házak késő középkori eredete nagy számú régészeti feltárás nyomán ismert. A tipikus, középső konyhából fütött háromosztatú házak megjelenését és elterjedését a 14-15. századra teszik. ${ }^{4}$

Bizonytalanabbak a régészeti és írott forrásokkal is nehezen adatolható szabadkémény megjelenésének körülményeire vonatkozó támpontok, hiszen ez a feltárások nyomán nem mutatható ki: a késő középkorban az Alföldön is füstös konyhákat feltételeznek. A szabadkémény a feltételezések szerint csak a hódoltság után, a 18. század folyamán terjedt el, és vált általánossá az ország középső részén.

Épületünk a szabadkéményes házak utolsó generációjához tartozik.

\section{A ház és telek anyagi kultúrájának fő vonásai}

A telek felső része a gazdasági udvar (3. kép). A telek háztól távolabbi részén a két telekrészt elválasztó meredek rézsút lankás feljáró bontja meg, amely az állatokkal való közlekedést tette lehetővé. A gazdasági udvarrészt drótfonatos kerítés határolta el a telek többi részétől, mely a lakóház délnyugati sarkától nyugat felé indult, majd déli irányban megtört, a meredek lejtő szélétől 3-4 méterrel bentebb. A ház délnyugati sarkánál, valamint a feljárat vonalában a kerítésen kiskapu nyílott. A gazdasági udvart északon a lakóház főhomlokzata határolta, keleten, az utcának háttal az istálló és a disznóól. Az istálló vályogból épült, utólagos tégla aláfalazással. A bejárat a homlokzat középtengelyében nyílik, két oldalán egy-egy kis fatokos, szárny nélküli, a behatolás ellen vas pálcával osztott ablakkal. A bejárati ajtó ún. váztáblázatos, egysze-

4 A régészeti kutatások eredményeire: Cseri - Tárnoki 2001., a szabadkéményről: Barabás 1970. 284., Barabás 1997., az Alföld népi építészetének kutatásáról összefoglalóan: Novák - Selmeczi 1989., a háromosztatú házak datálására legutóbb: Laszlovszy 2006. 
rű iparosmunka. Az istálló földpadlós, a bejárattól balra a keleti fal mentén és jobbra, a déli fal mentén egy-egy földbe vert karókon álló, az állatok kikötéséhez vaskarikákkal ellátott rúd, ún. süvegfa. Az istálló tetőszerkezetét körbefutó, sarkain összecsapolt fa koszorúgerenda fogja össze, melyet a hosszoldalakon két-két helyen kovácsolt vaspántokkal erősítettek egy-egy födémgerendához. A tetőt gyári hornyolt cserép fedi. Az északi oromfal deszkából készült, a déli tapasztott lécvázas, rajta három galambdúc-nyílással, a nyílások előtt fa polcokkal.

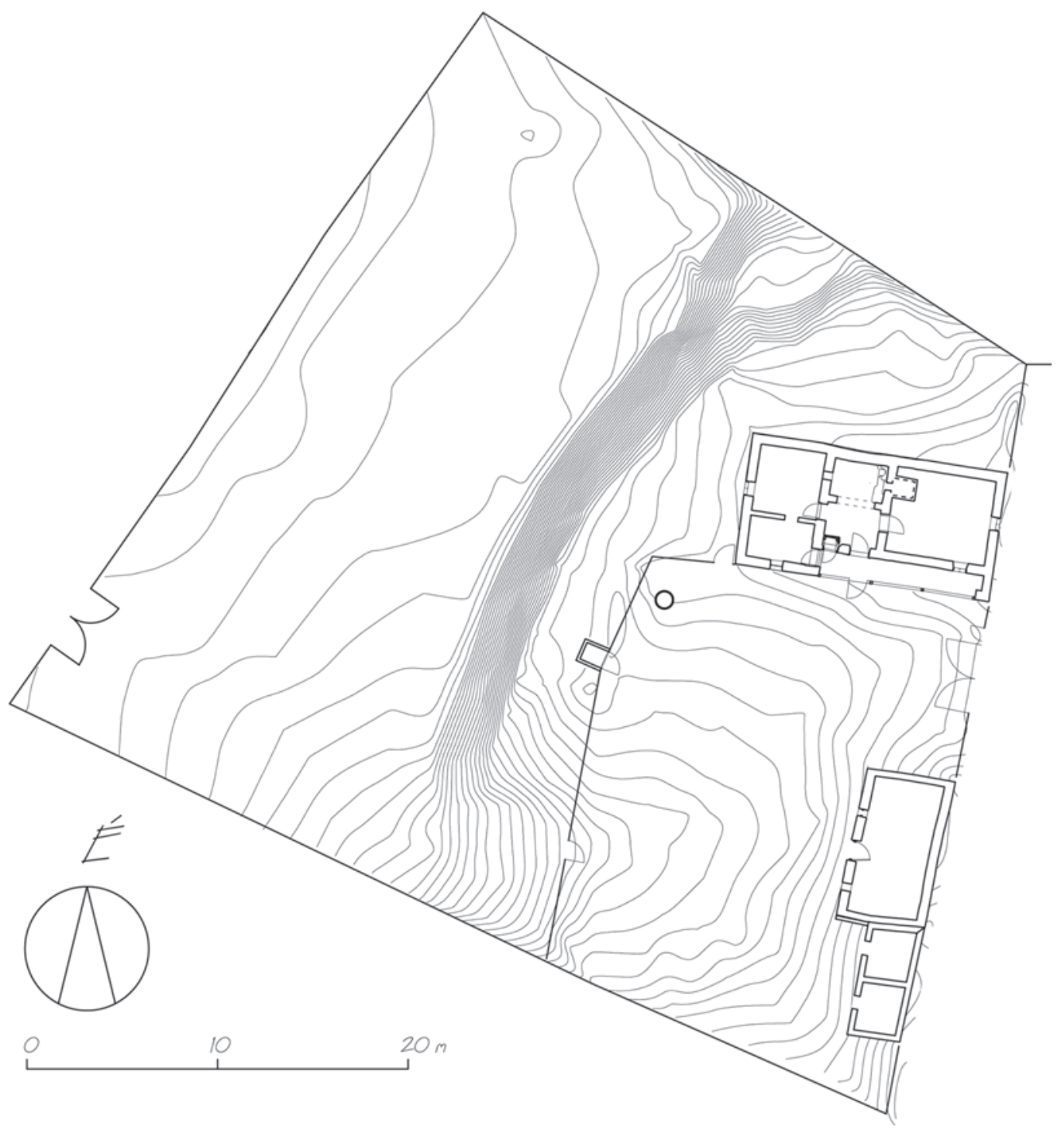

3. kép: A telek helyszínrajza (Felmérés: Rácz Miklós, Tölgyesi Levente)

Az udvar északnyugati sarkában található a kút. Ennek felül összeszűkülő belső falazata téglából készült, kávája betongyűrű, lenagyolt akácfa oszlopok által tartott kis tetővel fedett esztergált fahengeres felhúzóval. Az ól kis méretű téglából és kerámia falazóblokkokból épült, alacsony hajlású félnyeregtető fedi, hornyolt cseréppel.

A kúttól délre áll a tégla falazatú, cserépfedésű árnyékszék.

Az utca felőli kerítés, a kocsi- és gyalogkapu csúcsosra vágott végű fenyődeszkákból készült.

A lakóház 6,9×13,4 méter alapterületen áll, falai 46-50 centiméter vastagok, vályogtéglából épültek (4-7. képek). A ház hosszában háromosztatú, az első szoba 5,3 méter, a konyha és a pitvar 2,8 méter, a kisszoba és a kamra 3,4 méter hosszú. A pitvar és az első szoba előtt 1,3 méter széles faoszlopos tornác húzódik. 


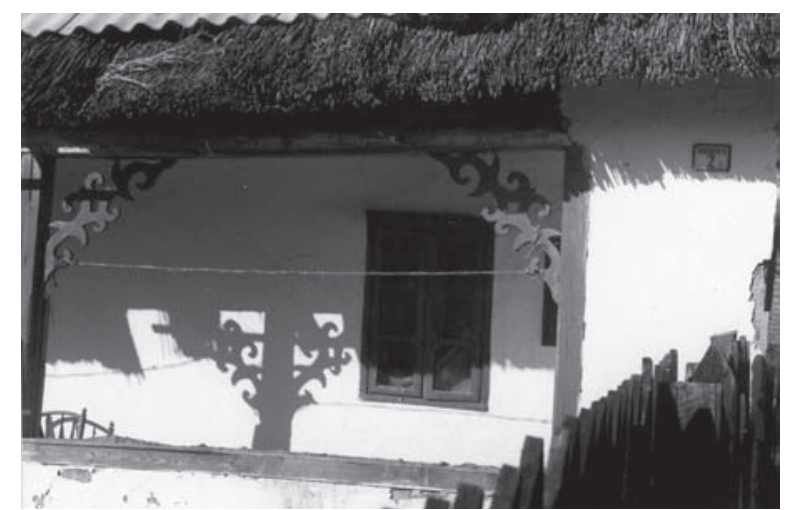

4. kép: A lakóház tornácának részlete, 1999.

A ház rövid homlokzatain egy-egy ablak található, az első szoba másik ablaka délre, a tornácra nyílik, és dél felé nyílik a kamra ablaka a tornác nélküli homlokzatszakaszon.

Az első szobán, valamint a pitvar-konyha között egyetlen mestergerenda húzódik végig, a ház hossztengelyével párhuzamosan pitvar és a konyha közötti szakaszon megkettőzve. A kisszoba és a kamra felett a ház hossztengelyére merőleges mestergerenda húzódik.

A mestergerendákra és a falkoronákra támaszkodva $60-80$ centiméterenként $10 \times 12-15$ centiméter keresztmetszetű fiókgerendák felett mintegy 10 centiméter vastag, nádból készült borítás és e felett 10-15 centiméter vastag saralás alkotja a ház födémét, mely felülről simítóréteggel le van tapasztva.

A ház tetőszerkezete a végfalakra és a két osztófalra állított, összesen négy, ún. ollószékre támaszkodik. E szerkezettípus a kutatás szerint a vert és vályog falszerkezetekkel párhuzamosan a 18. században terjedt el.

Az ollószékek taréjszelement tartanak, mely a ház egész hosszán végighúzódik (13,5 méter). A taréjszelemen egyetlen, vastagabb végén lenagyolt fenyőfa törzs (7. kép).

A taréjszelemenre és a falkoronákra helyezett égetett téglákra támaszkodtak a szarufák, hagyományos nevükön horogfák, melyeket párosával a gerincnél összecsapolva rögzítettek össze. Hasonlóképpen fa csapokkal rögzítették a lécezést. A tető faszerkezetén, így a taréjszelemen végein és a fürészelt szerkezeti elemek különböző részein kb. 5 centiméteres átmérőjü, funkció nélküli facsapok figyelhetők meg. Ezek a csapok az alapanyag úsztatással való szállítására utalnak: az egész törzseket (melyből egy teljes fatörzs alkotja a taréjszelement) végeiken összecsapolva, tutaj formájában úsztatták a történeti Magyarország területén elsősorban a Kárpátok erdeiből.

A tető végeit díszítetlen deszka oromfalak zárják le, az oromfalak alján deszkából fürészelt konzolokra támaszkodó vízvető deszkával. Az utca felőli oromfalon egyetlen, nagyjából középre helyezett, álló téglalap alakú szellőzőnyílás található, a hátsó oromfalon három, feltehetőleg házi galamboknak kialakított beugró vállú félköríves búvónyílás, körülöttük díszítésként fúrott lyukakkal.

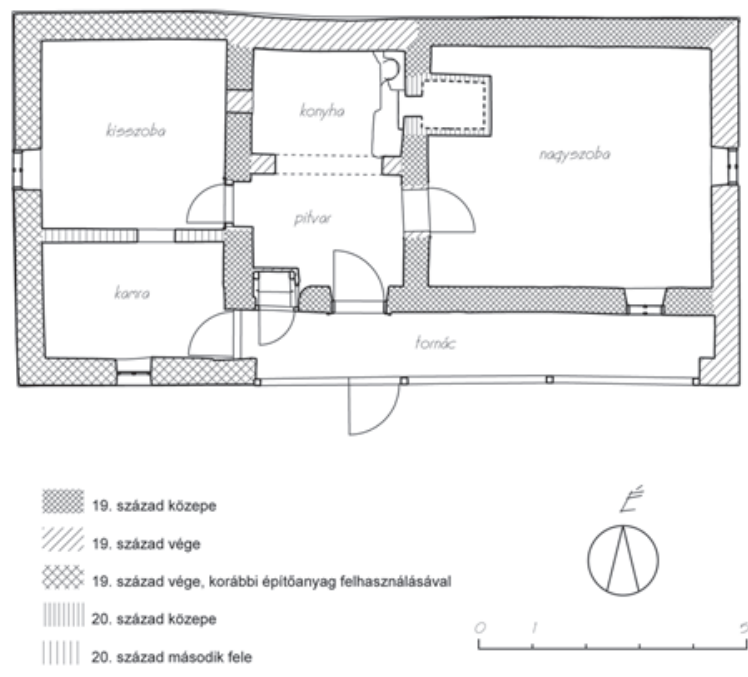

5. kép: A lakóház alaprajza az építési periódusok jelölésével

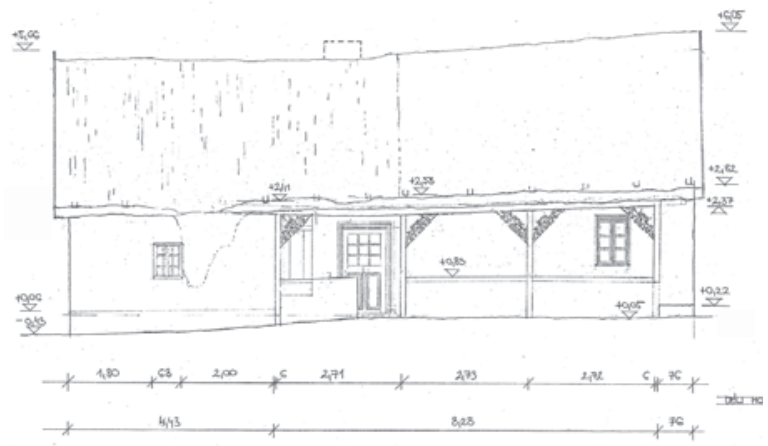

6. kép: A lakóház déli homlokzata, 2005.

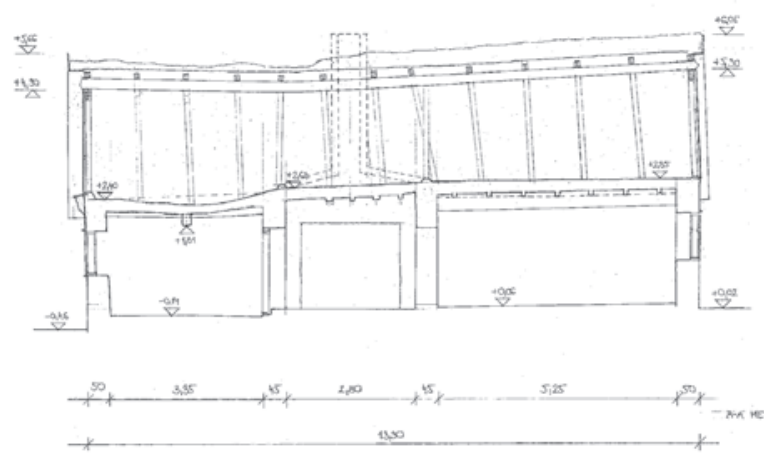

7. kép: A lakóház hosszmetszete, 2005. 
A konyhát égetett téglából és tégla méretű vályogból soronként váltakozva rakott dongaboltozat fedte. A boltozatot két vonóvas fogta össze, a konyha elülső hosszoldalának közepénél a boltozatra építve alakították ki a szabadkémény kürtőjét (8. kép). A felhasznált téglákon egységesen $\mathrm{BL}$ monogramos téglabélyeg található. ${ }^{5} \mathrm{~A}$ konyhában a nagyszoba felőli falhoz építve, falazott, tapasztott padka áll, melynek északi végében utólag átalakítás (utólagos kialakítás?) nyomait mutató beépített tűzhely maradványai találhatók. ${ }^{6}$ A padka a ház lábazatával megegyező vörösesbarna színű. A tűzhely az utolsó periódusban csak vízmelegítésre szolgált a felső részébe befalazott ónozott vas fazékkal. A padka felett nyílik a szobai kemence téglákból épült, boltozott nyilása.

A lakatlan épületben a kisszobában egy ágy, egy takaréktűzhely, a pitvarban egy egyszerủ munkaasztal és egy falra szegekkel erősített, egyszerű fa fogas, a kamrában egy falra szerelt polc volt. A kamrában kis fa ládákban nagy számú vastárgy volt a padlón. A házban összesen három régi keményfa szék volt, melyek mindegyike a 19. század végén, a 20. század elején készült, egyik parasztbútor, kettő polgári stílusú, üzemben készült bútor. Az ablakfülkében a

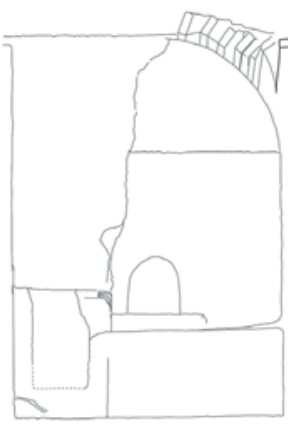

$04 a$

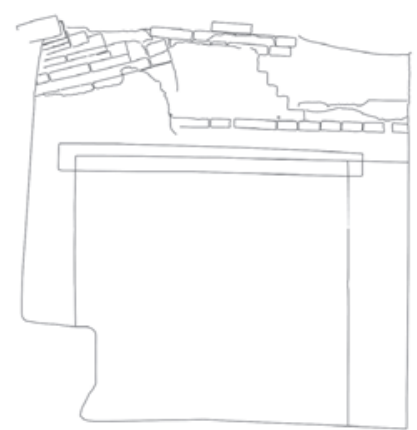

$04 d$

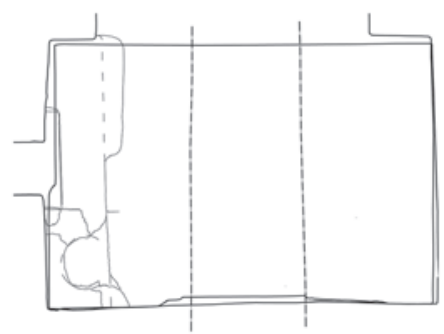

8. kép: A szabadkéményes konyha felmérési rajzai párkányon levelek és képeslapok voltak, melyeket az utolsó lakóhoz címeztek. A szobában egy keretezett kép is volt, melyben a 20. század elején készült színezett nyomat az ausztriai (Krajna) Veldes (ma Bled, Szlovénia) kirándulóhelyet ábrázolja (12. kép). Az emlék feltehetőleg a ház utolsó lakójához köthető.

A padláson található főbb tárgyi csoportokat a dobozokba gyűjtött üvegpalackok és befőttes üvegek, régi szerszámok, kötelek és zsinórok jelentették. A tetőszerkezetre akasztva főként lószerszámok, továbbá egy díszített bőröv volt található. A hagyományos erdélyi román népviselethez tartozó bőröv tarsolyrészébe hímezve román személynév és az 1897-es évszám olvasható (13. kép).

A padláson fekvő szerszámok nagy része a szántóföldi múveléshez köthető gyomlálószerszám, ún. acatoló, emellett egy kapa, egy csákány, egy disznóperzselő eszköz és egy szénavágó szerszám volt itt. A szerszám vésett felirata a házat lakó Gulyás család egy tagjához köthető: „Gujás János 1873” (14. kép). A szerszámok között feküdt egy kard is (15. kép). A padláson volt egy további fegyver, egy öntött vasból készült ún. boxer, mely a 19. század végére, 20. század elejére keltezhető.

A házban előkerült valamennyi érem értékét vesztett aprópénz (fillér, forint) volt.

\section{Az épületre vonatkozó vizsgálatok és megfigyelések}

A lakóház szerkezetein az építéstörténetre és periódusokra vonatkozó megfigyeléseket lehetett tenni azokon a pontokon, ahol a pusztulás révén sérültek a felületek, továbbá helyenként célzott feltárást is végeztem. A ház és a telek történetére vonatkozóan ezen kívül szóbeli információkat is lehetőség volt gyüjteni, és sikerült másolatot szerezni a ház lakóinak 1930 körül készült fényképéről (18. kép).

A ház elótti udvarrészen, a kamra előtt, annak falától mintegy 2 méterre 2006-ban korábbi gabonásverem vált láthatóvá. A méhkas alakú verem nem volt betöltve, csak lefedve, lefedése ekkor beszakadt. A gabonatárolásban a szakirodalomban a 19. század vége felé váltották fel a veremben való tárolást az újabb gabonatárolási módok.

Az épület használatának legutóbbi szakaszában valamennyi falfelület a gerendázatokkal együtt fehérre meszelt volt. A lábazatok a külső falakon vörösesbarna színűek voltak. A belső nyílászárók, az ablaktokok belső része és a belső ablakszárnyak szürke színűre, a nyílászárók kültéri felületei zöld színűre voltak festve.

A megismert első építési periódusra vonatkozóan a pitvar falain figyelhettünk meg festésrészleteket: itt a falak eleinte fehérek, majd az átépítést megelőző időszakban okkerszínúek voltak, kék pettyekkel. A második, a 19. század végétől vagy a századforduló tájától számított periódusban a pitvar folyamatosan egységes erős színeket - okker, világos piros, majd zöldeskék - kapott, később, már a második világháború után több periódusban me-

5 „1893. szeptember 20-án veszi meg a [Tiszaföldvári Polgári Társulati] Alap a Balogh Lázár által felkínált téglagyárat.” Vas 2002. 127. Ennek alapján a téglák készítése feltehetőleg 1893 előttre tehető.

6 „Az adatokból kirajzolódik, hogy az Alföld több vidékén a XVIII. században és a XIX. század első felében a középpadka volt az egyedüli nyitott tűzhely, és később kezdtek a kemence szája előtt tüzhelyet, majd arra katlant építeni." Juhász 1989. 204. 


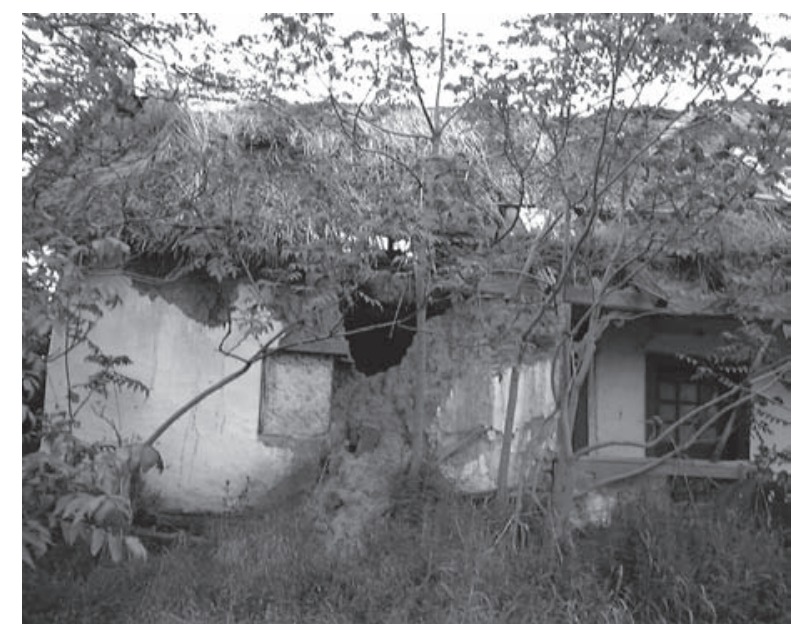

9. kép: A lakóház 2005-ben

szelésen kék illetve piros hengerelt mintájú díszítést alkalmaztak. A pitvar színei több esetben a konyhára is kiterjedtek, ahol csak a füstfogó gerenda aljának vonaláig festettek, e felett meszeletlen, kormos volt a felület. A konyhai tüzelőpadka általában szintén - feltehetőleg a pitvarral megegyezően - színes volt. A tornácon szintén részben a pitvar színei voltak megfigyelhetők. A meszelésrétegek a mindig fehér színű nagyszobában is nyújtottak támpontot a változások történetéhez. A tornácra néző ablak és a pitvarból nyíló ajtó körül a korábbi nyílásperiódusokhoz beforduló, illetve az átépítések által megszakított meszelési rétegsor volt köthető, melyeket az átalakítás utáni rétegsor fedett. A nyílászárókról megállapítható volt, hogy döntően a második építési periódushoz sorolhatók, s hogy ezek eredetileg kívül-belül sötétbarna színűek voltak. Az utcai ablak későbbi, tágabban a 20. század első évtizedeire datálható.

Több ponton lehetőség volt a falazat megfigyelésére is. Megállapítható volt, hogy az első építési periódusban jóval nagyobb, a fal teljes vastagságát átfogó, kb. 15×23×42 centiméter méretű vályogtéglákat használtak. A második építési periódusban és az 1940-es években ezzel szemben $15 \times 15 \times 30$ centiméter méretű vályogtéglákkal dolgoztak.

Megfigyelhető volt a régi építőanyag újrafelhasználása a második periódusban: az ekkor újjáépült hátsó helyiségek falainak alsó részét új anyagból építették, míg a felső szakaszhoz a bontott, nagy méretű vályogtéglákat használták fel, amely ezáltal 5-7 centiméterrel vékonyabb lett. A tornác mögötti falnál a falazat legalsó sora alatt egy egybefüggő, feltehetőleg döngölt felület volt megfigyelhető. Ez arra utal, hogy döngölt agyaggal készítették elő a falak helyét.

A pitvar és a szobák padlóját valamikor a 2. világháború után kátránypapírral, később PVC lemezzel burkolták, s ezek alatt megmaradtak a korábbi agyag padlók. A kisszoba és a kamra kivételével a padlók kutatható állapotban megőrizhetők voltak. A tornácon a felső padlószint alatt mintegy 10 centiméter mélységben a korábbi építési periódushoz tartozó padlót is megfigyelhettük a falfelületeken hozzá futó meszelésekkel együtt, ez a korábbi padló valószínűleg épen megvan a tornác területén.

7 A padlóátalakításokra a szerző nagyszüleinek tiszaföldvári háztartása nyújthat párhuzamot. Itt az agyag padlók az 1950-es évek végéig voltak használatban, ekkor itt is kátránypapírral fedték le a szobai padlót, majd az 1960-as években a konyhában műkő lapburkolat, a szobákban hajópadló készült, kivéve azt a szobát, ahol a szerző ekkor már idős, változtatásokra kevésbé nyitott dédanyja élt: itt még évtizedekig megmaradt a földpadló. 


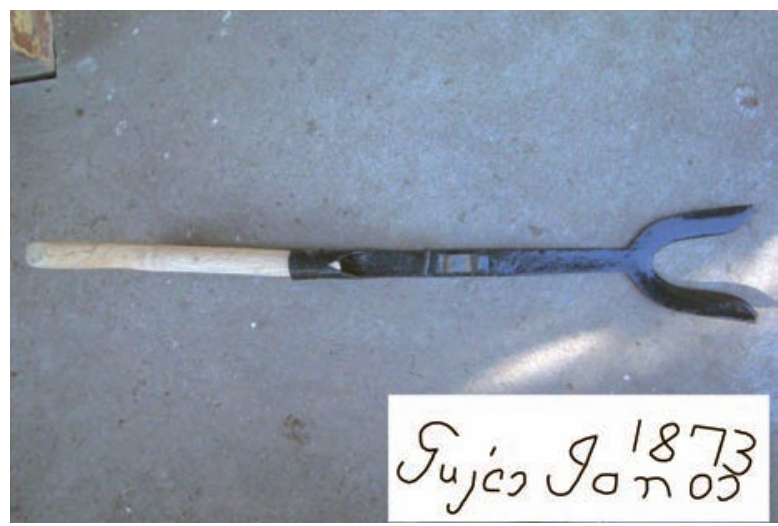

12. kép: A padláson előkerült szénavágó és felirata

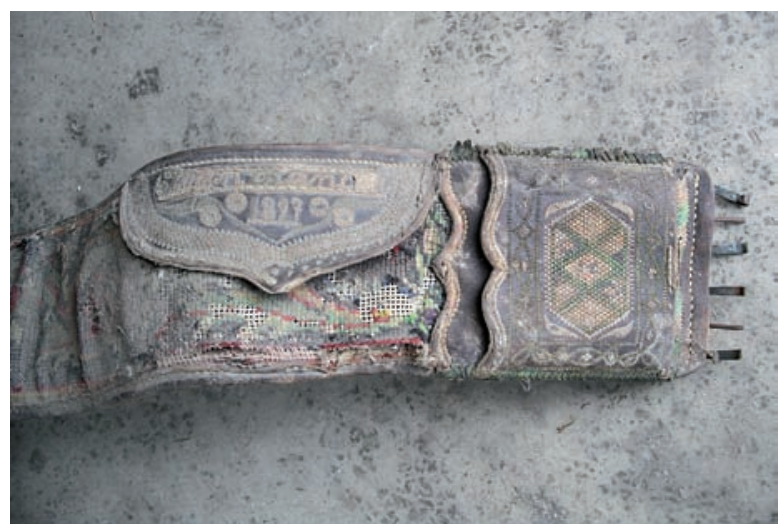

14. kép: A padláson előkerült 1897-es datálású román böröv

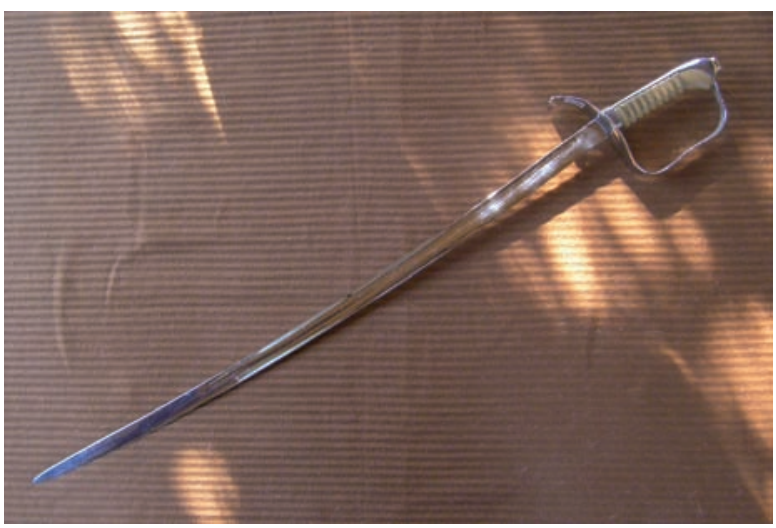

13. kép: A padláson elökerült kard restaurálva

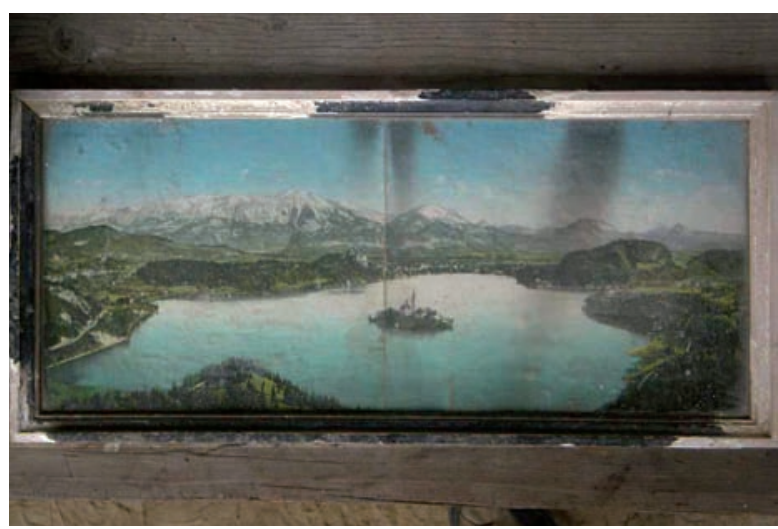

15. kép: Keretezett kép a ház nagyszobájából

A nagyszobában az agyagpadlóból vett mintát keresztmetszeti vékonycsiszolattal vizsgáltuk. ${ }^{8}$

A szakaszosan karbantartott, javított, illetve megújított padló teljes vastagsága 2,7 centiméter, mely egy legkorábbi, vékony felületről kiindulva teljes egészében a megújítások során keletkezett, és a hagyományos módon folyó fenntartása legkésőbb nagyjából az 1980-as évek elején zárult le.

A padló karbantartására, megújítására vonatkozóan szóbeli és szakirodalmi információval rendelkezünk. A tiszaföldvári adatközlők szerint a ledöngölt felszínen több rétegben ledöngölt agyagból alakították ki a padlót. A karbantartásra évente egyszer ${ }^{9}$, de egyes háztartásokban három alkalommal ${ }^{10}$ (kora tavasszal, nyáron és kora ősszel) került sor, ezt mázolásnak nevezték. A mázoláshoz híg agyagot használtak, melyhez ló- illetve marhatrágyát ${ }^{11}$, de egy adat szerint esetenként tejet is kevertek. ${ }^{12}$ Más háztartásokban csak marhatrágyát használtak a padlómázoláshoz. ${ }^{13} \mathrm{~A}$ takarítások alkalmával a padlót hetente vízzel áttörölték, a kisebb hibákat javították, ezt is nevezik mázolásnak. A padlókat az erre szolgáló lyukacsos edénnyel rendszeresen fellocsolták, benedvesítették.

A nagyszoba tornác felőli falánál megfigyelhető, hogy a falsíktól mintegy 1 centiméterrel beljebb egy néhány milliméteres meszelésrétegsor függőlegesen a padló teljes vastagsága alá fut. Ez megerősíti azt, hogy a jelenlegi padló nem a szoba legkorábbi padlója, hanem azt legalább egy alkalommal cserélték. A feltárás helyén tehető megfigyelések arra utalnak, hogy a korábbi padlókat nem lefedték, hanem elbontották és eltávolították.

A padlómintában a vékonycsiszolat alapján hozzávetőlegesen 29 réteget tudtunk elkülöníteni. $E$ rétegek feltehetőleg egy-egy mázolással azonosíthatók. Feltételezhető, de egyelőre nem erősíthető meg, hogy a padló az 1940 körüli, szóbeli információval adatolt felújításhoz köthető, és az évenkénti megújításaihoz egy-egy, a padló keresztmetszetében megfigyelhető réteg köthető. Bár az ehhez a felújítás során készült, utólagos aláfalazásként készült tégla lábazati falhoz való viszonyát nem tudtuk egyelőre megfigyelni, ez a beavatkozás olyan mérvű, amely nagy valószínűséggel új padló készítésével járhatott együtt.

8 A vizsgálatot Horváth Zoltán geológussal végezzük.

9 Jakab Mártonné (szül.: 1900.) elmondása, az adatokat Jeszenyi Tamásnak köszönöm.

10 Enyedi Ferencné Danku Jolán (szül.: 1927.) elmondása.

11 Az adatot Nagyné Lékó Máriának köszönöm.

12 Ld. 9. lj.

13 Rómer llona (szül.: 1939.) elmondása, Id. 10. Ij. 


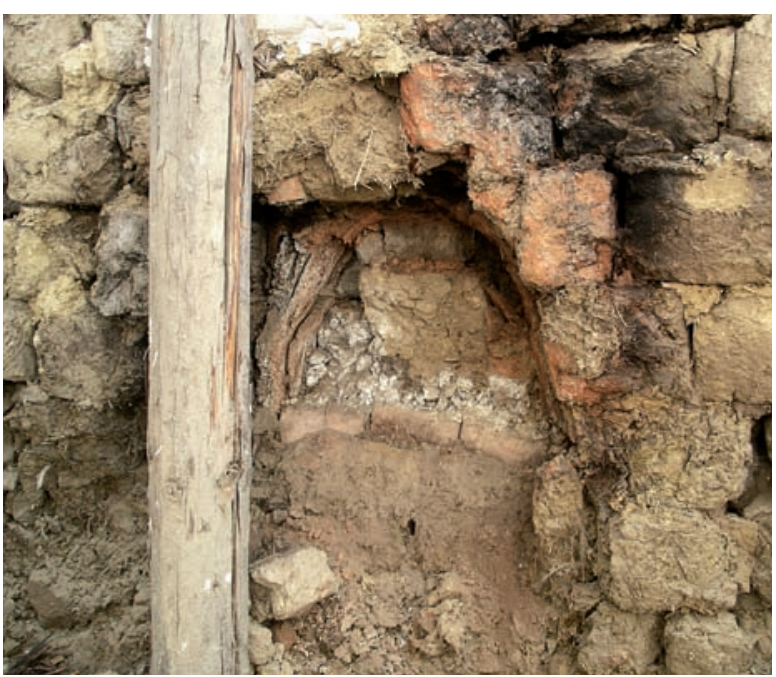

16. kép: Elfalazott kemencenyílás a konyha és a kisszoba között
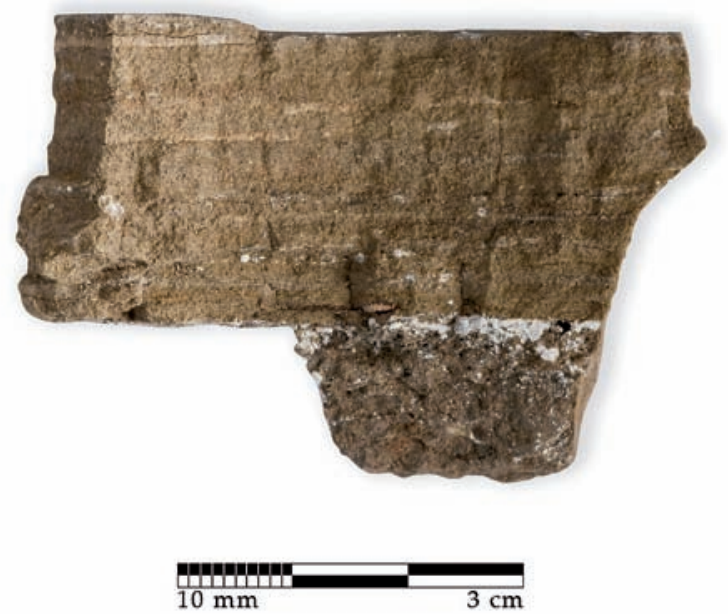

17. kép: Minta a nagyszoba padlójából

Írott és térképi források közül egyelőre egy jelentősebb adat emelendő ki.

A telek alaprajzára vonatkozó legkorábbi ismert térképes adatunk Tiszaföldvár kataszteri térképe, mely 1870-1890 között készült, pontosabb dátumát sajnos nem ismerjük. ${ }^{14} \mathrm{~A}$ térképen a telken maival azonos elrendezésben látható a lakóház és az istálló.

Az épület és a telek megismeréséhez a szóbeli források is sok fontos támpontot nyújtottak. Legfontosabb adatközlőm, Kertész Mihály az 1940-es években gyermekként és fiatalként ebben a házban élt. Tőle kaphattam információkat az ekkor végzett jelentős felújításról, a háború eseményeiről (az eredeti ajtók elszállítása a szovjet megszállás alatt fedezéképítéshez), a gazdasági udvar egykor fontos épületéről, a kocsiszínről, amely az istállóval szemben állt, továbbá eltűnt részletekről, mint a nagyszoba udvari falában az 1940-es években megszüntetett falitéka.

A ház utolsó lakója, Gulyás Pálné az anyakönyvi adatok alapján az alsó-ausztriai Wösendorfban született 1909ben, és a szóbeli információk alapján Ausztriában is nőtt fel, ahol családja akkor szolgált. Feltehetőleg ezzel a kapcsolattal magyarázható a házban talált bekeretezett kép, mely egy népszerű ausztriai üdülőhelyet ábrázol. Szintén szóbeli forrással adatolható, hogy adatközlőm édesapja, a század első felében a házban élő Gulyás házaspár veje a fővárosban csendőrként szolgált, és 1940 körül halt meg. A ház padlásán elókerült kard legnagyobb valószínűséggel az ő személye révén kerülhetett ide.

\section{A megfigyelések, vizsgálatok eredményei}

A megfigyelések eredményeként megállapítható, hogy a ház nagy átépítésére, amikor döntően jelenlegi formáját elnyerte, valamikor nagyjából 1880-1910 között került sor.

Biztosan ebből az átépítésből származik a konyha boltozata és kéménye, a két hátsó helyiség (újjáépítés), a tetőszerkezet és esetleg a tornác, két ablak, a bejárati ajtó.

Egy néhány évtizeddel korábbi, 1850-1870 tájára tehető építkezés eredménye az utca felőli két szakasz falai, a nagyszoba és a pitvar födémje. E korszakhoz boltozott szegmensíves nyílásfülkék tartoztak, de korabeli nyílászárók nem őrződtek meg. Talán nem tévedünk nagyot, ha a szénavágó szerszám vésett feliratán 1873ban nevét megörökítő Gulyás Jánost tartjuk a mai ház legkorábbi részei építőjének. A tetőszerkezet faanyaga a Kárpátokból úsztatással való szállításhoz köthető, a taréjszelemen mérete miatt az úsztatásra alkalmas folyó szorosabb közelségéhez kötött (a ház 1,5 kilométerre áll a Tiszától).

Erről a periódusról tudjuk, hogy mindkét szobában kemence állt, és a hátsó kis szobában egy meg nem határozható időpontban, de az 1930-as évek előtt a kemence oldalánál beépített tűzhely is volt.

Az 1940-es években nagyobb javítást végeztek a házon. A 2. világháború utáni évtizedekben a házat egy gyermektelen házaspár és a férj nőtlen fivére lakta, utóbbié volt a kisszoba és feltehetőleg a kamra. Egyrészt a lakók családi helyzete, másrészt szegénysége járulhatott hozzá ahhoz, hogy a ház az archaikusnak számító szabadkéményes konyhával változtatás nélkül érte meg a 20. század végét.

A tornác, a pitvar és részben a konyha a ház fennállása során többnyire változatos színúek illetve mintásak voltak, míg a lakószobák, és a tornáctól eltekintve a külső falak mindvégig fehérre voltak meszelve.

14 http://www.archivportal.arcanum.hu/kataszter/ 


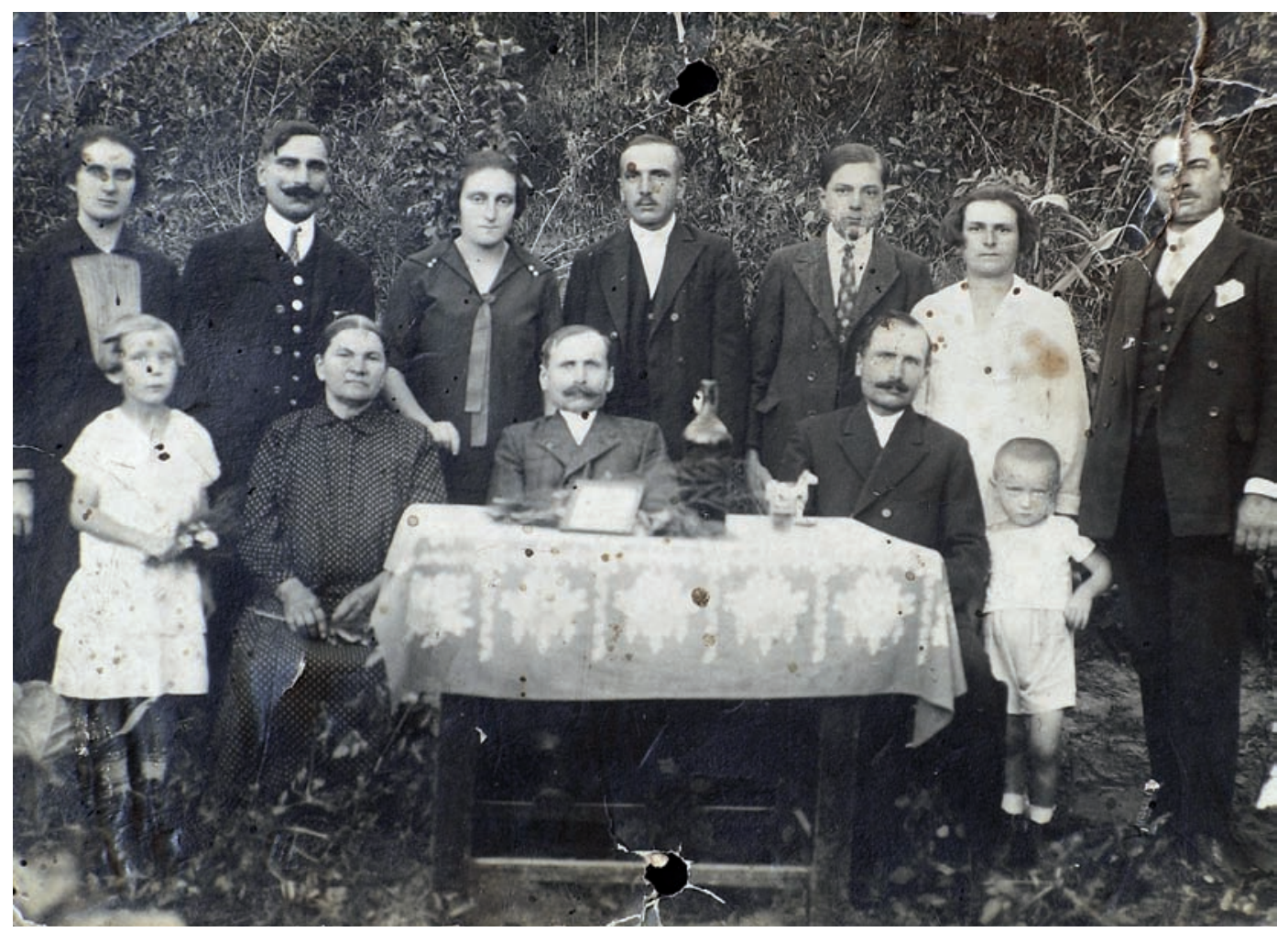

18. kép: A Gulyás család 1930 körül. A kép feltehetőleg a ház kertjében készült, a képen látható kisgyermek Kertész Mihály (szül.: 1925.)

Az épület hagyományos, elvileg azonos eljárással készült sajátos elemei, az agyag padlók az utólagos roncsolástól és a talajban lejátszódó változásoktól nagyrészt megkímélve kivételes lehetőséget nyújtanak a szerkezeti és természettudományos (pl. archeobotanikai) vizsgálatra, az összehasonlító elemzésekre. A nagyszoba mai padlója feltehetőleg az 1940 körüli megújítástól datálható, míg a tornácon a jelenlegi alatt az ennél korábbi padló is megvan.

A lakóházban található tárgyak jellegzetessége, hogy esetünkben összességében a régi, több évtizedes vagy több, mint fél évszázados tárgyak túlnyomó részt képviseltek a házban maradt leletanyagban és különösen igaz ez a padlás tárgyegyüttesére. Hangsúlyozni kell ugyanakkor, hogy a tipikusan mai pusztásodás társadalmi, településtörténeti körülményei eltérnek a középkorban jellemző pusztásodásoktól. Az épületegyüttes sajátossága esetünkben, hogy az alárendeltebb építmények az újabb építésűek a telken, ezek képviselik a „,korszerűbb" szerkezeteket: a teljes egészében falazóblokk illetve tégla építésű ól, illetve árnyékszék, ezeknél régebbi a vályog építésű istálló, s a legrégibb, ezeknél jóval korábbi épületrészeket a lakóházban találjuk meg.

\section{Zárszó}

Tanulmányomban egy régészetileg már részletesebben kutatott háztípus történeti fejlődésének utolsó, kortárs stádiumát az Alföld egyik utolsóként épült, és legtovább fennmaradt háromosztatú szabadkéményes lakóházának konkrét példájával, régészeti szempontokra koncentrálva kívántam bemutatni. A számos eddig feltárt, és remélhetőleg a jövőben feltárandó falusi lakóépület részletes vizsgálatától némileg eltávolodva, de azt nem szem elől tévesztve egyetlen mai, azokhoz szorosan kötődő ház közeli tanulmányozása, úgy gondolom, tanulságos lehet: az épülettípus vonatkozásában kiváló történeti perspektívát jelent, másrészt az épület teljes építészeti kontextusa, és az itt rendelkezésre álló jelentős tárgyi, írásos és szóbeli emlékanyagának összefüggései a régészeti kontextusok számottevő új elemzési és értelmezési lehetőségeire mutathatnak rá.

A lakatlanná vált, pusztuló ház tárgyi anyaga leletegyüttesként tekinthető, $s$ bár régészetileg általában nem feltárható elemeket (papír, bőr, fa) is tartalmaz, egyenértékűen kezelendő és vizsgálható a teljes pusztulás után feltárt leletegyüttesekkel. 
A tárgyakat itt mintegy pillanatfelvételként a leletanyag pusztuló részével együtt, a hozzájuk tartozó szóbeli és írott forrásokkal együtt, ugyanakkor az épület térbeliségében tudjuk megfogni és megmutatni, ezáltal szemléltetve a régészeti korú hasonló lelőhelyek elveszett dimenzióit a régészetileg kutatott épületekkel minden aspektusában azonos jellegű, de korban hozzánk igen közeli lelőhely esetében.

Az épület történeti célú megismerésének és kutatásának végül határt szabott, hogy a vele való foglalkozás célja a ház megőrzése és a műemléki szempontú helyreállítás volt (19-20. képek). ${ }^{15}$ A szerkezeti felújítás, részleges újjáépítés révén egy újabb építési periódus vette kezdetét, melynek során nem csak a megőrzés, használat és bemutatás, hanem a történeti emlékként való megismerés is alapvető szempontot jelent.

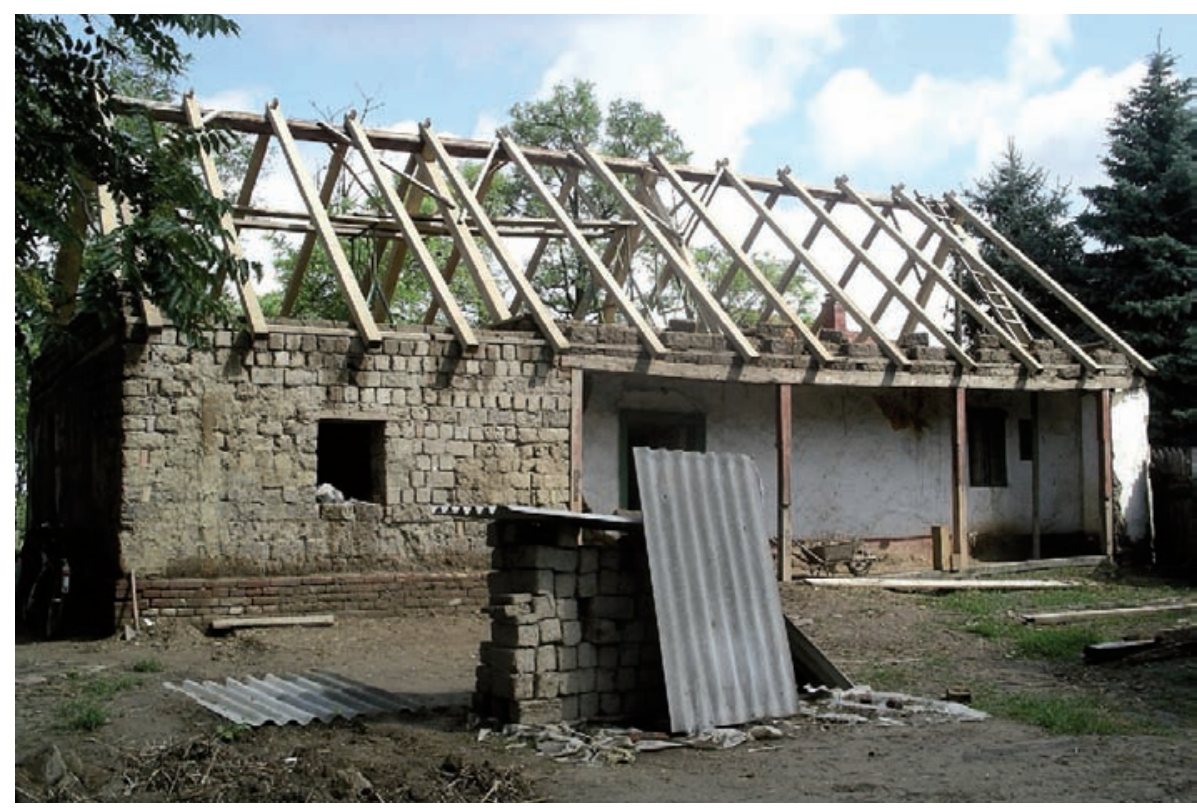

19. kép: A ház szerkezeti rekonstrukciója

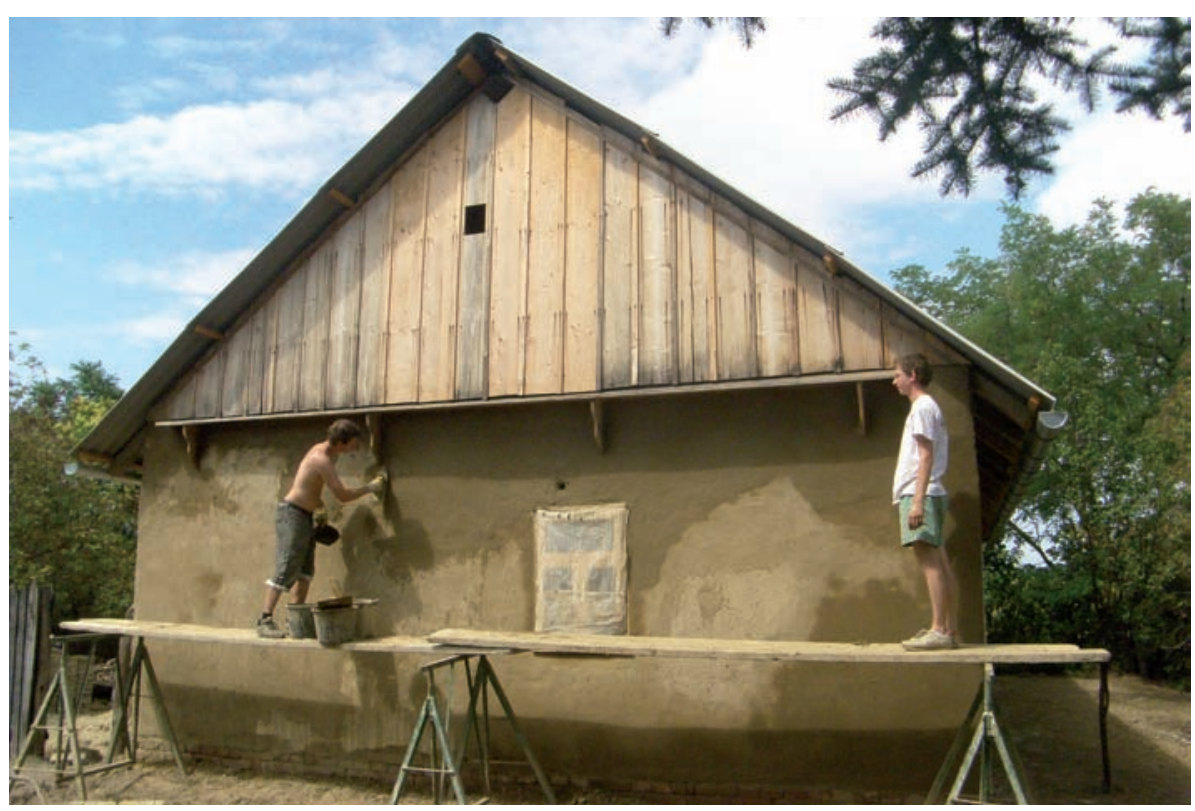

20. kép: A keleti homlokzat felújítás alatt, 2012.

15 Rácz 2012. A szerző ezúton mond köszönetet mindazoknak, akik az eddigi kutatást és felújítást munkájukkal, közreműködésükkel segítették. A 2012. évi felújítási munka a Falufejlesztési Társaság „Nagyapám Háza” programjának keretében valósult meg, a munkában részt vettek Lencsés Albert és Tari Bálint építészhallgatók (BME). 


\title{
Material culture of a contemporary vernacular house in the Great Hungarian Plain
}

\author{
MIKLÓS RÁCZ
}

In this paper I am examining the archaeological aspects of a vernacular house that became derelict in the late 1990s. The house and its outbuildings were abandoned and began to deteriorate. The process of decay progressed to such an extent that by around 2005 the buildings and their inventory could be considered as an archaeological site and its archaeological material at the first stage of site formation.

As the first archaeological spect we are presenting the material culture of the buildings and the inventory of objects found in the abandoned house and considering possibilities of interpretation.

As the second aspect we discuss the building archaeology of the house based on the site observations during reconstruction works.

The house is one of the last standing examples of the so-called open chimney house orgininating from the 18th century that is characterised by a single chimney in the middle of the house rising from the vault over the kitchen, collecting the smoke from the ovens in the rooms and from cooking in the kitchen.

The oldest parts of the house were built around 1850-1870 and a major reconstruction was undertaken around 1880-1910. The different types of adobe bricks and the features of renewed adobe plaster enabled us to divide the main building phases (Fig. 5).

Timber of the reconstruction of around 1880-1910 was brought through rafting on the nearby river Tisza from the Carpathian mountains.

The inventory of the abandoned house proved to be significantly older than the date of abandonment, some special objects having been able to be connencted with oral information.

A distinct area of research is focused on the mud floors. A preliminary structural analysis of a sample from the floor of the main living room revealed a sequence of thin strata that can be connected to the yearly renewal of the floor (Fig. 17). The floors preserved in various rooms of the house also give an opportunity for further structural and scientific analysis.

\section{Irodalom}

Berényi M. - Buzás M. 2002.: A csíkszentsimoni lakóház bontása kapcsán. Ház és Ember 15. 221-230.

Bagi G. 2002.: Tiszaföldvár története a honfoglalástól 1876-ig. In.: Kelemen - Pató - Szlankó 2002. 49-77.

Balassa I. (föszerk.) 1997.: Magyar Néprajz IV. Anyagi kultúra 3. Budapest

Bálint J. 2010.: Egy bükkaranyosi lakóház bontása. Ház és Ember 22. 67-86.

Barabás J. 1970.: A lakóház füsttelenítéséről. Ethnographia 81. 276-286.

Barabás J. 1997.: A magyar népi építészet történetének korszakai. In.: Balassa 1997. 289-308.

Bellon T. - Szabó L. 1987.: Szolnok megye népművészete. Budapest

Buzás M. - Vass E. 2011.: A homoródalmási építészeti kutatások eredményei. Ház és Ember 23. 21-51.

Cseri M. - Tárnoki J. (szerk.) 2001.: Népi építészet a Kárpát-medencében a honfoglalástól a 18. századig. A Jász-NagykunSzolnok Megyei Múzeumok Közleményei 58. Szentendre-Szolnok

Holcsek E. - Balázsik T. 2009.: A Kővágóörs, Jókai u. 18. sz. alatti népi lakóépület szondázó falkutatása, és XVIII. század végi fazekas égetőkemencéjének feltárása. Müemlékvédelem 53. 139-145.

Juhász A. 1989.: Adatok a XVIII-XIX. századi alföldi ház kéményéhez és konyhai tüzelőberendezéséhez. In.: Novák - Selmeczi 1989. 195-208.

Kelemen É. - Pató M. - Szlankó I. (szerk.) 2002.: Tiszaföldvár. Fejezetek a város történetéből. Tiszaföldvár

Kiddey, R. - Schofield, J. 2010.: Digging for (Invisible) People. British Archaeology 113. 18-23.

Laszlovszky J. 2006.: Későközépkori falusi lakóház Tiszaugon. Az alföldi lakóház kialakulásának kérdéséhez. Studia Caroliensia 2006/3-4. 295-314.

Novák L. - Selmeczi L. (szerk.) 1989.: Építészet az Alföldön I. Az Arany János Múzeum Közleményei Vl. Nagykőrös

Rácz M. 2012.: Egy parasztház megőrzése és rekonstrukciója Tiszaföldváron. Tájházi Hírlevél 2012/2. 3-11.

Sabján T. 1998.: Egy lakóház bontása a Szentendrei-szigeten. Ház és Ember 12. 241-250.

Tóth B. 2005.: A csíkmenasági Adorján-ház. Ház és Ember 18. 11-28.

Vas B. 2002.: A „maga keze által”. Ipartörténeti áttekintés. In.: Kelemen - Pató - Szlankó 2002. 111-129. 
